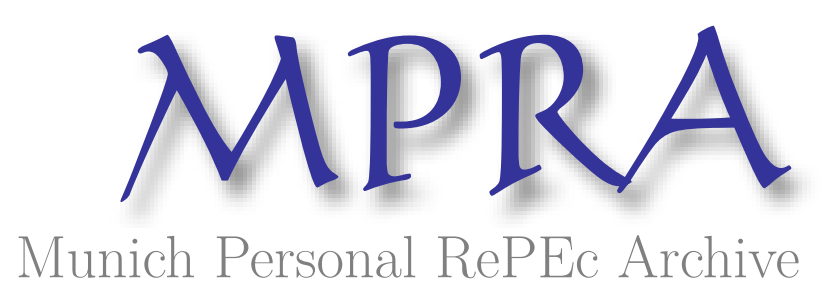

\title{
Overcoming Innovation Limits through Outward FDI: The Overseas Acquisition Strategy of Indian Pharmaceutical Firms
}

Pradhan, Jaya Prakash

Institute for Studies in Industrial Development

July 2008

Online at https://mpra.ub.uni-muenchen.de/12362/

MPRA Paper No. 12362, posted 26 Dec 2008 06:49 UTC 


\title{
Overcoming Innovation Limits through Outward FDI: The Overseas Acquisition Strategy of Indian Pharmaceutical Firms
}

\author{
Jaya Prakash Pradhan*
}

(Version 1.0, July 2008)

\section{ISID}

Institute for Studies in Industrial Development

4, Institutional Area, Vasant Kunj, New Delhi - 110070

*Assistant Professor at the Institute, Email: pradhanjayaprakash@gmail.com 


\section{Contents}

Abstract 1

1. Introduction 1

2. Developing local technological capability 2

3. OFDI to overcome innovation limits 5

3.1. Emergence of Indian pharmaceutical OFDI 7

3.2. Cases of leading Indian acquirers $\quad 10$

3.2.1. Ranbaxy Laboratories Ltd. 11

3.2.2. Strides Arcolab Ltd. 15

3.2.3. Glenmark Pharmaceuticals Ltd. 16

3.2.4. Sun Pharmaceutical Industries Ltd. 18

3.2.5. Dr. Reddy's Laboratories Ltd. 19

4. Concluding Remarks 22

Table-1 Trends of Indian Greenfield Pharmaceutical OFDI Flows, 1977-2007 8

Table-2 Overseas Acquisitions by Indian Pharmaceutical Firms, 2000-08 9

Table-3 Regional Pattern of Overseas Acquisitions by Indian Pharmaceutical Firms, 9 2000-08

Table-4 Selected Leading Indian Acquirers Based on Number of Acquisition Deals 12 Conducted during 2000-08

Figure-1 A simplistic Perspective on Technological Capabilities of Indian 4 Pharmaceutical Firms

Figure-2 Possible Effects of Outward FDI 6

Figure-3 Indian Pharmaceutical Greenfield OFDI, 1977-March 2007, In US \$ million 8 


\title{
Overcoming Innovation Limits through Outward FDI: The Overseas Acquisition Strategy of Indian Pharmaceutical Firms
}

\begin{abstract}
A host of strategic government policies including a process patent regime led to the rise of Indian pharmaceutical firms with significant process development capabilities. With policies getting liberalized overtime and a product patent regime in place, now firms' survival crucially depends on their abilities to develop new products and brand creating exercise. Indian pharmaceutical firms with their inadequate product development capabilities are clearly at serious risk. In this context, an increasing number of Indian pharmaceutical firms are observed to be using acquisition as a strategy to overcome their limited innovation strength by accessing new products and their technologies, skills and new markets. Overseas acquisitions represent both challenges and opportunities for Indian pharmaceutical firms aspiring to emerge as global entities based on advance technologies.
\end{abstract}

Keywords: Indian pharmaceutical industry; Outward FDI; Overseas Acquisition.

\section{Introduction}

India is among a few developing countries to succeed in building strong local capability in the technology-intensive pharmaceutical sector ${ }^{1}$. Presently Indian pharmaceutical industry has indigenous technological and productive capabilities to meet up to 70 per cent of the domestic requirement of bulk drugs and almost all the demands for formulations ${ }^{2}$. Its cost-effective technological capabilities not only restrict imports from developed countries into India, but also generate rising trade surpluses in pharmaceutical products by exporting to over 65 countries $^{3}$. In a sense, India has emerged as a major developing country competitor in the world pharmaceutical market.

With over 16000 pharmaceutical units, Indian pharmaceutical industry is one of the largest and most advanced among developing countries that produces life-saving drugs belonging to all major therapeutic groups at a fraction of prices existing in the world market. The industry today possesses the largest number of US Food \& Drug Administration (USFDA) approved manufacturing facilities outside the US and has been filing more number of Drug Master Files (DMFs) with the USFDA for drug exports to the US than that filed by Spain, Italy, China and Israel taken together ${ }^{4}$.

Considering the 1950s period when India hardly had any base in pharmaceutical sector, these achievements are truly remarkable for a developing country. The role of strategic government policies has clearly been critical in local technological developments that took place in Indian pharmaceutical industry. These government policies led the initial capability formation

\footnotetext{
${ }^{1}$ China, Singapore, Korea, Czech Republic, Brazil, and Argentina are other developing countries that have important base in pharmaceutical sector.

2 Department of Chemicals and Petrochemicals (2000), Annual Report 1999-2000, Ministry of Chemicals and Fertilizers, Government of India, New Delhi.

${ }^{3}$ Organization of Pharmaceutical Producers of India (2004), 'Indian Pharmaceutical Industry - Fact Sheet 2004', available at http://www.indiaoppi.com/keystat.htm

${ }^{4}$ Deccan Herald (2005), 'Drug patent: A Viagra for Indian pharmaceutical industry’, April 4.
} 
to produce modern drugs locally by establishing public-owned companies and allowed reverse engineering-based technological change for domestic private-owned companies.

However, the setting of technological developments adopted by Indian companies was lopsided. Local innovation has been mostly limited to cost-effective process development and firm-specific R\&D (Research \& Development) strategy grossly neglected new product developments. While weaker intellectual property rights stimulated process innovation by Indian companies in the past but in subsequent period they emerged as an important obstacle to advance technological developments and learning. With globalization and liberalization, Indian pharmaceutical firms are increasingly forced into world market and their inadequate product development capabilities are likely to marginalize their future growth and expansion. In this backdrop, the role of outward FDI can be instrumental for Indian firms to overcome this particular limitation in their innovation strategy. Through overseas acquisitions Indian pharmaceutical firms can quickly enlarge their product portfolios and intangible asset bundle by adding new technologies, managerial and marketing skills.

This paper has examined the ways by which outward FDI can help Indian pharmaceuticals firms to overcome their inadequate capabilities for product innovation. Section 2 explores the main mechanisms through which India has built its technological base in the pharmaceutical sector and spell out how they have restricted innovation activities of Indian firms to just process developments. Besides considering the technological benefits that overseas acquisitions have on acquiring Indian pharmaceutical firms, Section 3 focuses on trends and geographical pattern of Indian pharmaceutical OFDI. It also presents a series of short case studies related to five largest acquirers from Indian pharmaceutical sector. These case studies primarily based on company annual reports, company press releases and newspaper reports seek to identify the main motivations of acquisitions that are available from managerial comments and perspectives. These case studies are to address the basic question of this paper: Are Indian pharmaceutical companies using overseas acquisition to overcome their limited product development technological capabilities? Section 4 concludes the paper.

\section{Developing local technological capability}

In the initial period during 1950s-60s, the Indian pharmaceutical industry was largely dominated by foreign enterprises and possessed hardly any local productive capability based on indigenous raw materials. Foreign firms, enjoying a strong patent protection under the Patent and Designs Act 1911, were averse to local production and mostly opted for imports from home country as working of the patent. The absence of domestic competition and product patent regime provided foreign firms with abnormal monopoly power to charge higher prices for their drugs. Foreign firms even with their shallow specialization centered on trading activities could reap extraordinary profits (Rs. 600 crore annual sales for an investment of less than a few crore!) (Joseph, 1979). Further, these foreign firms tend to operate in lucrative pharmaceutical segments rather than meeting demand for essential life saving drugs. While the existing product patent regime arrested the potential of local knowledge developments via incremental innovation, 
general Indian population suffered most during this period under the consistent scarcity of essential medicines and surging drug prices.

These adverse situations, namely inadequate technological capabilities of the domestic sector to start local production and hesitation of foreign firms to do so, called for active policy interventions and the Indian government decided to intervene through direct public sector investment. This led to the establishment of the Indian Drugs and Pharmaceuticals Ltd. (IDPL) plants at Rishikesh and Hyderabad in 1961 and the Hindustan Antibiotics at Pimpri, Pune, in 1954 to manufacture penicillin. The starting of the public sector enterprises has been an important step towards scaling up indigenous technological capability of Indian pharmaceutical sector as they assumed the initiative in producing bulk drugs indigenously and led to significant knowledge spillovers on the domestic private sector. In addition, government has initiated building national institutions for creating scientific, managerial and general skills, which shall be readily and cheaply available to the industry for productive purposes.

The positive role of direct public sector investment in local technological progress has been complemented by the enactment of the Indian Patent Act (IPA) 1970 and the New Drug Policy (NDP) 1978 in the 1970s. The IPA 1970 brought in a number of radical changes in the patent regime by reducing the scope of patenting to only processes and not pharmaceutical products and also for a short period of seven years from the earlier period of 16 years. It also recognizes compulsory licensing after three years of the granting of the patent. The enactment of the process patent regime contributed significantly to the local technological development via adaptation, reverse engineering and new process development (Aggarwal, 2007; Pradhan and Alakshendra, 2006). As there exists several ways to produce a drug, domestic companies innovated cost-effective processes and flooded the domestic market with cheap but quality drugs. This led to the steady rise of the domestic firms in the market place. The NDP 1978 has increased the pressure on foreign firms to manufacture bulk drugs locally and from the basic stage possible. Foreign ownership up to 74 per cent under the Foreign Exchange Regulation Act (FERA) 1973 was permitted to only those firms producing high technology drugs. Foreign firms that are simply producing formulations based on imported bulk drugs were required to start local production from the basic stage within a two-year period. Otherwise, they were required to reduce their foreign ownership holding to 40 per cent. New foreign investments were to be permitted only when the production involves high technology bulk drugs and formulations thereon.

The outcome of the strategic government interventions in the form of a soft patent policy and a regime of discrimination against foreign firms affected the industry with a time lag and provided strong growth impetus to the domestic sector during 1980s. Domestic enterprises based on large-scale reverse engineering and process innovation achieved near self-sufficiency in the technology and production of bulk drugs belonging to several major therapeutic groups and developed modern manufacturing facilities for all dosage forms like tablets, capsules, liquids, orals and injectibles. These had a lasting impact on the competitive position of the domestic firms in the national and international markets. In 1991, domestic firms have emerged as the main players in the Indian market with about 70 and 80 per cent market shares in the case of bulk drugs and formulations respectively (Lanjouw, 1998). The industry turns out to be one of the 
most export-oriented sectors in Indian manufacturing with more than 30 per cent of its production being exported to foreign markets (Pradhan, 2007). The trade deficits of the seventies have been replaced by trade surpluses during 1980s.

Although the Indian policy regime has succeeded in building local capability in pharmaceutical sector but it has also created a number of limitations in pushing forward firm's productivity and technological activities (Figure-1). It is noteworthy that Indian domestic pharmaceutical companies now have advantage of innovative cost-effective processes, discovery in novel drugs delivery system, self-reliance in producing quality raw materials and production led by quality management. However, these technological strengths are confined to a small group of large Indian pharmaceutical companies. Indian pharmaceutical industry hosts a total of 16326 units of which just 123 units are large-sized (Pradhan and Sahu, 2008). Clearly, majority of the Indian pharmaceutical companies suffered from limitation of financial, technical and skill resources to undertake any kind of $R \& D$ activities. It is estimated that $R \& D$-doing firms constitute about just 18 per cent among small pharmaceutical firms whereas they respectively account for 32 and 52 per cent among large- and medium-sized pharmaceutical firms during 1991-2005. Notably, the R\&D intensity of large firms has gone up significantly from 0.15 per cent in 1990-91 to 5.62 per cent in 2004-05 and that of medium and small pharmaceutical firms fluctuated below 1 per cent mark.

\section{Figure-1 A simplistic Perspective on Technological Capabilities of Indian Pharmaceutical Firms.}
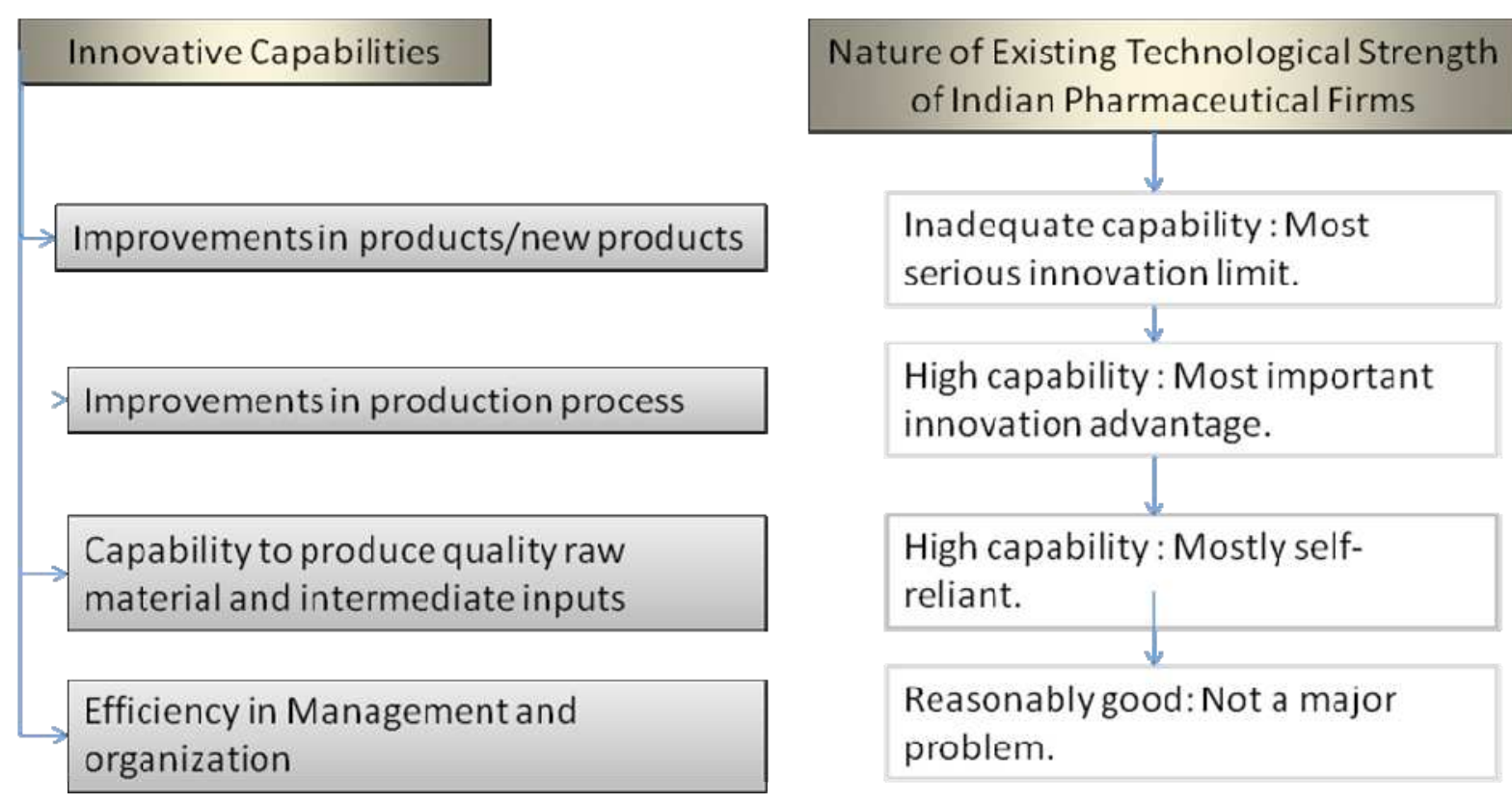

Adding to the limitation of a small number of Indian pharmaceutical firms undertaking $R \& D$ is the fact that such $R \& D$ expenses are not only of minimal amount, but have also been predominantly for process technological activities. The process patent regime that remained in 
place throughout 1972-2005 incentivized the process of technological change in a narrow range to improvements in production process, raw material and intermediate inputs. Indian companies had little inducement to undertake research for product developments as other Indian companies can legally launch any new product by simply resorting to another new process. As a result, firm-level capability in product developments was significantly undermined and for a long time. With cost-effective processes, Indian companies have focused on the low end of value-chains in pharmaceuticals like producing generics than opting for branded products or supplying bulk drugs to global players than market formulations of their own. Moreover, the fragmented domestic markets protected from external competition have actually ushered an era of price competition in the domestic market, which was essentially achieved via new cost-efficient process rather than the non-price competition based on quality and frontier innovation. Limited innovation or incremental innovation alone defines the criteria for firms' survival and growth under the contemporary protected domestic market and process patent regime.

However, the weakness of this limited innovation strategy for firm growth is quite obvious with the implementation of liberalization measures with regard to the Indian pharmaceutical industry like permission to 100 per cent inward FDI under automatic route and widespread import tariff reductions on pharmaceutical products and machinery. The competition faced by Indian pharmaceutical firms is increasingly globalizing with competitive sources shifting from low price advantage to those based on product innovation, quality, skill and product differentiation. The adoption of product patent regime by India in mid-2000s required that Indian firms now adopt new forms of innovation, i.e. product innovation if they like to survive. The growing competition also requires them to expand their market focus from local to overseas markets.

\section{OFDI to overcome innovation limits}

With markets and competition getting globalized, the innovation strategy of Indian pharmaceutical firms require a major transformation with increasing focus on quality and product development, which were hitherto neglected. They are urgently required to set up inhouse R\&D centre and allocate substantial financial and skill resources for both process and product developments to face imminent competitive challenges. Such product-oriented R\&D investments are not only risky, but also involve long gestation period with uncertain outcome. Apparently, the route of high cost in-house R\&D for enlarging product portfolio is a suitable long-term technological strategy for Indian pharmaceutical firms but would obviously not serve their purpose of meeting imminent competitive pressures being unleashed by liberalizing policies.

In this context, outward FDI can allow Indian pharmaceutical firms to overcome their most important innovation limit of inadequate product development capability. Indian firms rather putting their scare resources in long-term high-cost innovation strategy can simply acquire foreign companies with new product portfolio and advance technologies. Such strategic assetseeking OFDI immediately upgrade acquiring firms to a higher scale of technological 
specialization and diversification and offer a way to overcome entry barriers that exist in accessing developed countries markets. Added to these positive spinoffs, acquiring Indian firms are likely to derive immediate market expansion, economies of technological and business synergies, and to access new marketing skills, overseas sales distribution networks, and organizational knowledge (Figure-2).

Figure-2: Possible Effects of Outward FDI

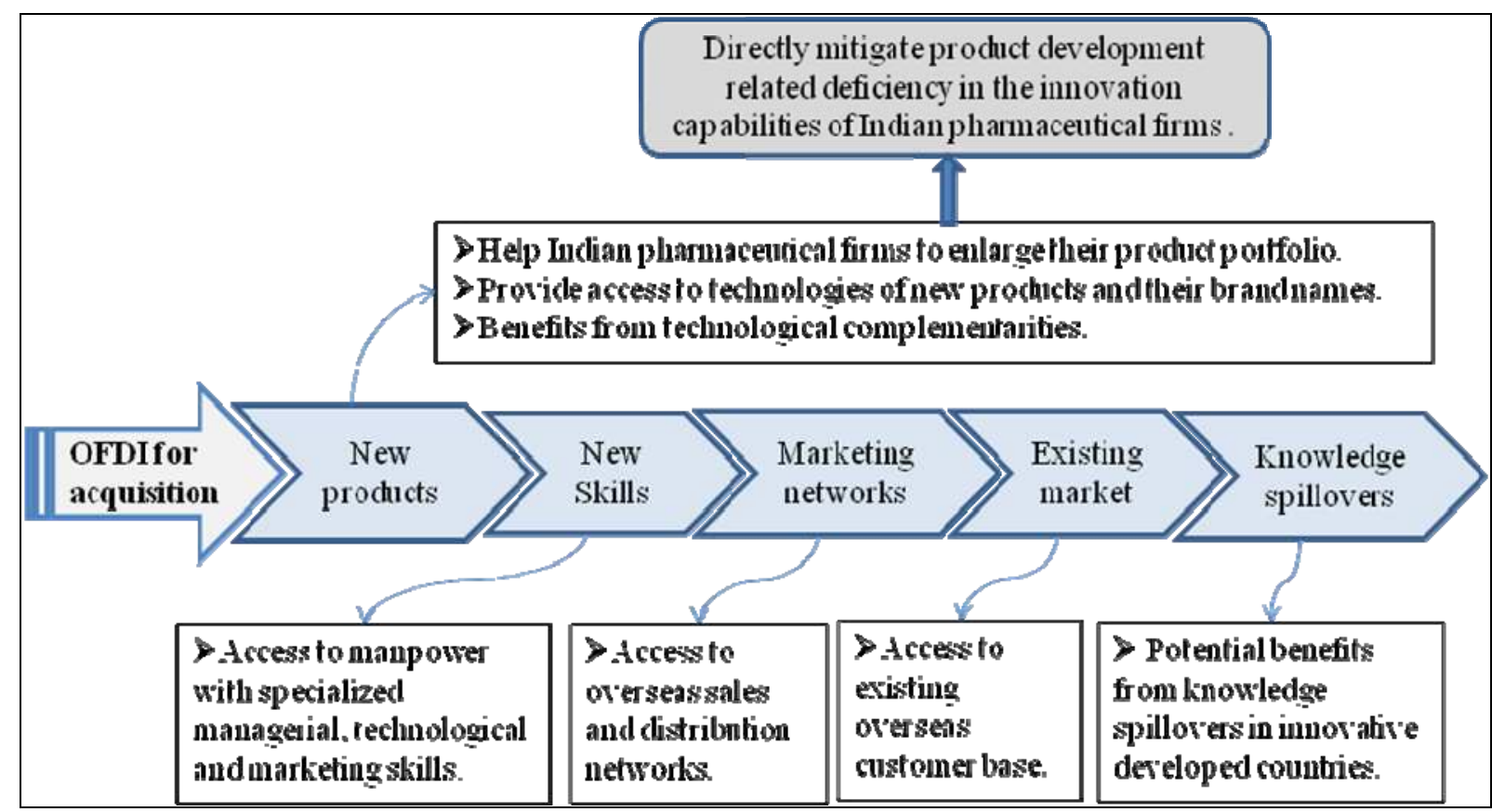

The physical presence of Indian companies through greenfield and brownfield OFDI in innovative developed countries also provide opportunities for considerable technological and organizational learning simply because of proximity to innovative competitors. Indian pharmaceutical firms can absorb knowledge-spillovers from large scale R\&D activities that are actually going on in developed countries and global market pressures shall in turn keep them on the path of constant learning and technological improvements.

Recently, a number of Indian firms are realizing that building sustainable competitive advantage in global markets requires more than just undertaking greenfield OFDI to exploit ownership advantages based on process technologies. Brownfield OFDI or acquisition is required to collect considerable knowledge on product developments and access trade-supporting infrastructure in foreign countries. As a result, they are now adopting an aggressive acquisition strategy with multiple firm-specific objectives like access to markets, products, technologies, marketing networks and to reap operating business synergies. Up to the end of 1990s, OFDI activities by Indian pharmaceutical firms have been largely in greenfield mode and since 2000 such activities are increasingly dominated by overseas acquisitions. 


\subsection{Emergence of Indian pharmaceutical OFDI}

The emergence of Indian pharmaceutical OFDI can be traced back to two Nigerian joint venture OFDI projects undertaken by two Indian firms between 1977 and 1982-one established by Ranbaxy Laboratory Limited in 1977 and another by Unique Pharmaceutical Laboratories in 1982. Another four Indian companies, namely Ambalal Sarabhai Enterprises, Glenmark Pharmaceuticals, Lupin Laboratories and Hoechst India (a subsidiary of a German company) joined the OFDI process during 1983-89. Except one case of investment made by Ambalal Sarabhai Enterprises in UK, Indian pharmaceutical OFDI during 1977-1989 was confined to developing countries such as Nigeria, Malaysia, Nepal, Kenya, Indonesia and Thailand. The prevailing process technological advantages achieved by Indian pharmaceutical firms under the liberal patent regime appear to be the central force behind their OFDI activities. They were motivated to exploit their ownership advantages based on cost-effective process innovation in other developing countries having liberal patent policies.

With the growing process technological capability of Indian firms and off-patenting of many modern drugs since 1990, Indian pharmaceutical OFDI assumed greater scale and high degrees of geographical specialization in 1990s. A total of 61 Indian pharmaceutical companies undertook US \$212 million worth of investment in 43 host countries in the 1990s (Table-1, Figure-3). Nearly 36 per cent of this aggregate investment has gone into developing countries. During this period a shift in the Indian policy regime occurred that allowed global competition into the pharmaceutical sector through inward FDI and imports of drugs. New competitive pressures in turn forced Indian pharmaceutical firms to expand their market focus and to improve their technological profile to include product development capability. The forthcoming product patent regime in 2005 and compulsory adoption of good manufacturing practices further diminished the traditional importance of process development capabilities in firms' survival and growth strategy. This made Indian pharmaceutical firms more conscious about the importance of global markets and new sources of competitiveness like quality, product development capabilities and constant innovation in management system.

The period 2000-07 witnessed a sharp rise in the size of outward Indian pharmaceutical investment led by an increasing number of Indian parent companies. Unlike in the past, a significant chunk of Indian pharmaceutical OFDI in early 2000s was to acquire new products and foreign knowledge to overcome existing limitations in their innovation strategy. From existing official sources, it is difficult to arrive at the magnitude of strategic asset-seeking OFDI in total pharmaceutical OFDI from India. The official statistics, among other limitations, capture only a part of total overseas acquisitions done by Indian firms (see Pradhan, 2008 for more detail). As the majority of overseas acquisitions concluded by Indian firms is led by substantial resource mobilization from overseas sources including foreign affiliates of Indian firms, Indian official sources only include a part of finance that Indian parent companies transfer from India to abroad for acquisition. Therefore, the estimated US \$2.7 billion pharmaceutical outward FDI obtained from different official statistics has been termed as greenfield in Table-1. Given the imperatives of Indian pharmaceutical firms to expand their market size and acquire firm-specific assets, it is not surprising that overwhelmingly Indian pharmaceutical FDI during 2000-07 has 
gone into innovative developed countries with large-sized pharmaceutical market. Developed region hosts as high as 88 per cent of Indian pharmaceutical FDI in this period. The relative significance of pharmaceutical OFDI in Indian manufacturing OFDI is also quite substantial for recent periods. Unlike pre-1990s period where Indian pharmaceutical firms contributed minimal amount, but have accounted remarkably higher share at 33 per cent in 2000-07 (Figure-3).

Figure-3 Indian Pharmaceutical Greenfield OFDI, 1977-March 2007, In US \$ million.

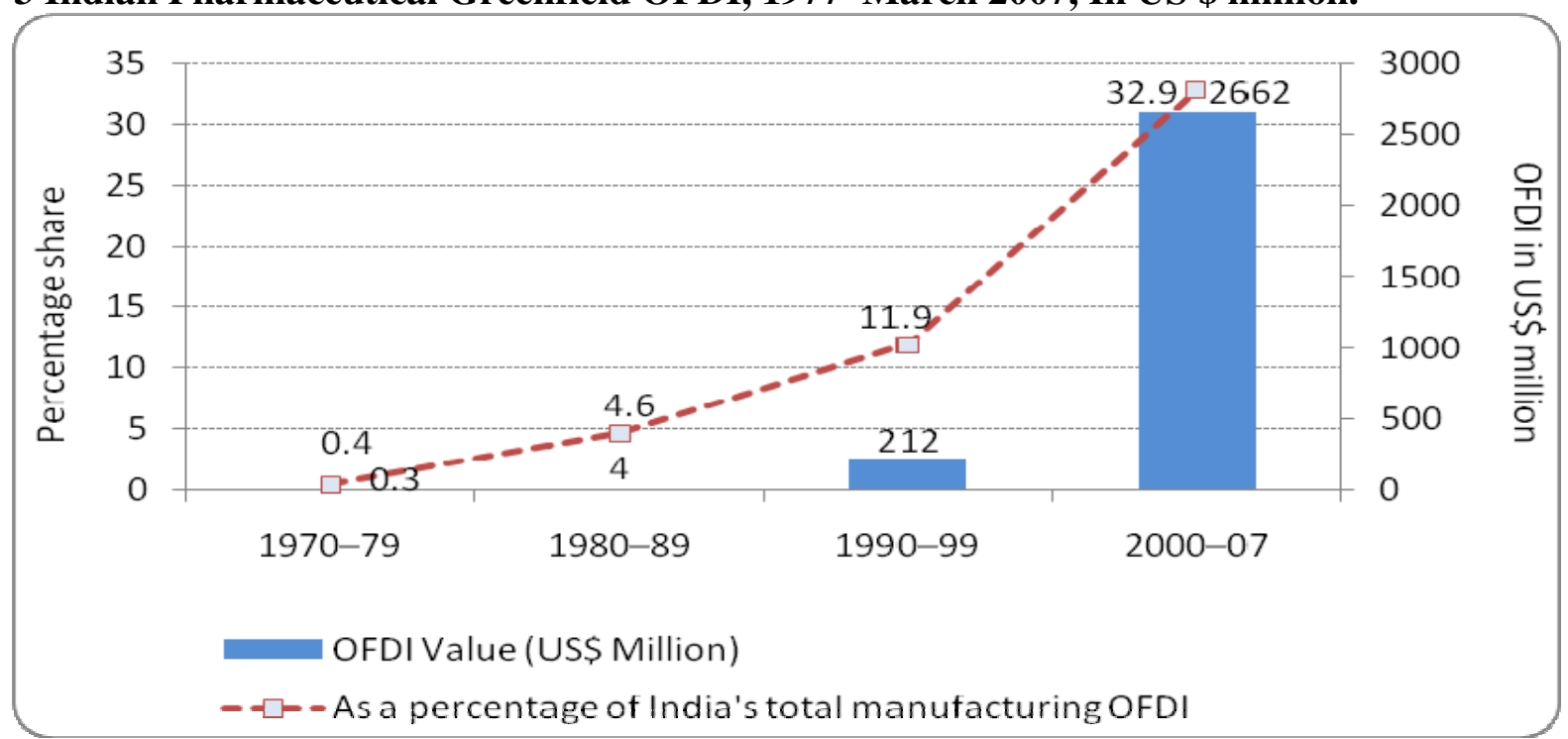

Note \& source: Same as Table-1

Table-1 Trends of Indian Greenfield Pharmaceutical OFDI Flows, 1977-2007

\begin{tabular}{|l|c|c|c|}
\hline Period & $\begin{array}{l}\text { FDI Value (US \$ } \\
\text { Million) }\end{array}$ & $\begin{array}{l}\text { No. of Indian Investing } \\
\text { Firms }\end{array}$ & $\begin{array}{l}\text { No. of Host } \\
\text { Countries }\end{array}$ \\
\hline $1970-79$ & 0.3 & 1 & 1 \\
\hline $1980-89$ & 4 & 5 & 7 \\
\hline $1990-99$ & 212 & 61 & 43 \\
\hline $2000-07 * *$ & 2662 & 121 & 47 \\
\hline All Years & 2878 & 158 & 57 \\
\hline
\end{tabular}

Note: * Data for 2001 is only from January to March, 2002 is from October to December and 2007 data is from January to March.

Source: Calculation based on a dataset compiled from unpublished remittance-wise information from Reserve Bank of India, published reports of Indian investment centre and unpublished firm-level information from Ministry of Commerce.

Table-2 presents a summary of trends in overseas acquisitions made by Indian pharmaceutical firms over 2000-March 2008 based on a dataset compiled from different sources. It can be seen that overseas acquisitions by Indian pharmaceutical firms is a recent phenomena that is gaining a substantial dimension in terms of value and number of acquiring Indian companies. The value of 105 overseas acquisitions done by a total of 43 Indian pharmaceutical 
companies targeted at 28 countries stood at US $\$ 2.9$ billion during 2000-2008. In terms of geographical focus, Indian pharmaceutical acquisitions spread across a total of 19 developed countries and 9 developing countries (Table-3). Developed region with 82.6 per cent share in total acquisition value is clearly the leading host location for these acquisition activities. Such concentration of Indian pharmaceutical acquisitions in developed region is indicative of the trend that Indian pharmaceutical firms were compelled to use acquisition as a strategy to overcome their prominent innovation limit, namely inadequate product development capabilities. Skillintensive and R\&D-oriented developed countries are thus emerging as attractive destinations for Indian firms seeking new products and new markets.

Table-2 Overseas Acquisitions by Indian Pharmaceutical Firms, 2000-08

\begin{tabular}{|l|c|c|c|c|}
\hline \multirow{2}{*}{ Year } & $\begin{array}{c}\text { Acquisition in US\$ } \\
\text { million }\end{array}$ & \multicolumn{3}{|c|}{ In Number } \\
\cline { 2 - 5 } & Value & $\begin{array}{c}\text { Acquisition } \\
\text { deals }\end{array}$ & $\begin{array}{c}\text { Acquiring } \\
\text { Indian firms }\end{array}$ & $\begin{array}{c}\text { Target } \\
\text { countries }\end{array}$ \\
\hline 2000 & & 2 & 2 & 2 \\
\hline 2001 & & 1 & 1 & 1 \\
\hline 2002 & 12.8 & 6 & 3 & 5 \\
\hline 2003 & 114.3 & 6 & 6 & 4 \\
\hline 2004 & 68 & 10 & 8 & 8 \\
\hline 2005 & 472.8 & 28 & 16 & 16 \\
\hline 2006 & 1359 & 28 & 20 & 13 \\
\hline 2007 & 773 & 19 & 15 & 13 \\
\hline $2008 *$ & 74 & 5 & 5 & 5 \\
\hline All Years & 2873.9 & 105 & 43 & 28 \\
\hline
\end{tabular}

Note: *- Data is from January to March.

Source: Based on dataset constructed from different reports from newspapers, magazines and financial consulting firms like Hindu Business Lines, Economic Times, Financial Express, Business World, Grant Thornton India, etc.

Table-3 Regional Pattern of Overseas Acquisitions by Indian Pharmaceutical Firms, 2000-08

\begin{tabular}{|c|c|c|c|}
\hline \multirow{2}{*}{ Region/country } & Acquisition in US\$ million & \multicolumn{2}{|c|}{ In Number } \\
\cline { 2 - 4 } & Value & Acquisition deals & Acquiring Indian firms \\
\hline Developed region & 2373.9 & 86 & 41 \\
\hline Australia & 17 & 4 & 4 \\
\hline Belgium & 279 & 3 & 3 \\
\hline Canada & & 1 & 1 \\
\hline Czech Republic & & 1 & 1 \\
\hline Denmark & 6 & 3 & 3 \\
\hline France & 86 & 6 & 5 \\
\hline Germany & 652 & 2 & 2 \\
\hline Hungary & & 2 & 2 \\
\hline Ireland & 150 & & \\
\hline
\end{tabular}




\begin{tabular}{|l|c|c|c|}
\hline Israel & 454 & 2 & 1 \\
\hline Italy & 2 & 4 & 3 \\
\hline Japan & 3 & 3 & 3 \\
\hline Norway & & 1 & 1 \\
\hline Poland & 8 & 2 & 2 \\
\hline Spain & 66 & 4 & 3 \\
\hline Sweden & & 1 & 1 \\
\hline Switzerland & 77 & 3 & 2 \\
\hline UK & 156.9 & 15 & 13 \\
\hline USA & 417 & 28 & 20 \\
\hline Developing region & 500 & 19 & 11 \\
\hline Argentina & & 1 & 3 \\
\hline Brazil & 36 & 5 & 1 \\
\hline Bulgaria & 7 & 1 & 4 \\
\hline China & 6 & 5 & 2 \\
\hline Mexico & 59 & 2 & 1 \\
\hline Romania & 321 & 1 & 2 \\
\hline South Africa & 70 & 2 & 1 \\
\hline Thailand & & 1 & 1 \\
\hline Venezuela & 1 & 1 & 43 \\
\hline All Regions & 2873.9 & 105 & 1 \\
\hline
\end{tabular}

Note \& source: Same as Table-2.

\subsection{Cases of leading Indian acquirers}

Table-4 presents 13 leading overseas acquirers from Indian pharmaceutical industry. Most of these acquiring Indian firms are industry leaders in India. Their emergence and growth have co-evolved with numerous public policies to support the domestic sector like starting of public sector drugs companies, government research laboratories, adoption of process patent regime, fiscal incentives for indigenous $\mathrm{R} \& \mathrm{D}$, etc. These firms through substantial knowledge creation in new process development outcompeted dominant foreign players to emerge as key players in the domestic market and to build their internationalization strength through exporting.

With the implementation of new technological policy regime warranted by TRIPs in the home country and traditional export markets, these Indian domestic firms realized that their existing process-oriented technological capabilities are not adequate enough for meeting global competitive challenges. Three amendments to Indian Patent Act in 1999, 2002 and 2005 respectively provided for the provision of exclusive marketing rights, extension of patent duration to 20 years with reversion of burden of proof from patentee to defendant in issues of process patent infringement, and introduction of product patent protection.

In view of these changes in regulatory regime, the focus of leading Indian pharmaceutical firms started shifting from knowledge creation for new process to new product and brand. It is not surprising that these firms have chosen overseas acquisition as a strategy to achieve multiple 
objectives of new markets and new products. The broad range of their acquisition activities involved product and brand acquisitions, world-class manufacturing facilities and taking over of companies with significant intangible assets like products and technologies. This strategic assetseeking objective of leading acquiring Indian firms can be seen from short cases of five individual companies, which are discussed below.

\title{
3.2.1. Ranbaxy Laboratories $\mathrm{Ltd}^{5}$.
}

Ranbaxy Laboratories is the most aggressive overseas acquirer from Indian pharmaceutical sector with 11 acquisition deals spread across 10 countries. The company was early to recognize the imperative of TRIPS regime and inadequacy of its process development capabilities accumulated under an inward-looking development strategy. In his message to the shareholders of the company, Mr. Tejendra Khanna, Chairman, Ranbaxy Laboratories emphasized this fact very clearly:

\begin{abstract}
"As we approach the WTO deadline of January 1, 2005, for aligning our domestic patent laws to conform to the TRIPS Agreement (Trade Related Intellectual Property Rights), it is clear that domestic pharmaceutical companies will have to rely more for their future growth on developing new products from their own research and development efforts and less on producing and marketing of reverse engineered drugs.” Pp. 2, Ranbaxy Annual Report 1999.
\end{abstract}

Apart from undertaking necessary reorientation of its in-house research activities to include product development, Ranbaxy has used acquisition as a strategy to simultaneously access new products and new markets. In September 1995, it has acquired Ohm Laboratories with the basic objective of accessing latter's advanced manufacturing capabilities and technological processes to create quality branded and generic OTC products. According to the company press release, this acquisition has offered "a comprehensive development scale up and manufacturing of a diversified line of over-the-counter and Rx generic pharmaceuticals ${ }^{6}$." In April 2000, Ranbaxy Laboratories has acquired Bayer's German generic business portfolio that includes 20 marketed generic products with all their formulations. The acquisition of the fully automated manufacturing and packaging line facility with state-of-the-art testing and quality assurance capabilities from New York based Signature Pharmaceuticals Inc. in July 2002, provided Ranbaxy Laboratories' access to advanced research and development capabilities for manufacturing and distribution of controlled substances. 'Signature's acquisition provides strategic platform to Ranbaxy's US operations vis-à-vis liquid dosage forms" is what Dr. Brian Tempest, President, Pharmaceuticals, Ranbaxy Laboratories commented upon this acquisition.

\footnotetext{
${ }^{5}$ Ranbaxy Laboratories is in the process of being acquired by Japanese company Daiichi Sanyo since June 2008. However, the rise of Ranbaxy Laboratories and its internationalization process until now represent the experiences of a domestic-owned Indian pharmaceutical company.

${ }^{6}$ Ranbaxy Press Release (2002), 'Ranbaxy acquires liquid manufacturing facility from Signature Pharmaceuticals Inc. USA', July 23,
} 
Table-4 Selected Leading Indian Acquirers Based on Number of Acquisition Deals Conducted during 2000-08.

\begin{tabular}{|c|c|c|c|c|}
\hline $\begin{array}{l}\text { Name of Acquiring } \\
\text { Firm }\end{array}$ & $\begin{array}{c}\text { Value (US\$ } \\
\text { million) }\end{array}$ & $\begin{array}{c}\text { Number of } \\
\text { acquisition deals }\end{array}$ & $\begin{array}{c}\text { Name of target } \\
\text { countries }\end{array}$ & Description of acquisition deals \\
\hline $\begin{array}{l}\text { Ranbaxy Laboratories } \\
\text { Ltd. }\end{array}$ & 471 & ( & $\begin{array}{l}\text { Germany, South Africa, } \\
\text { Spain, Belgium, USA, } \\
\text { Spain, Japan, France, } \\
\text { Romania, Italy }\end{array}$ & $\begin{array}{l}\text { Strategic stake or acquisition of Germany-based generic business of } \\
\text { Bayer AG, South Africa-based Be-Tabs Pharmaceuticals, Spain- } \\
\text { based Efarmes' generic products, Belgium-based Ethimed NV, } \\
\text { manufacturing facility of US-based Signature Pharmaceuticals Inc, } \\
\text { Mundogen generic business of GlaxoSmithKline, Japan-based } \\
\text { Nihon Pharmaceuticals, generic business of Aventis SA, Romania- } \\
\text { based Terapia SA; unbranded generic business of Allen S.p.A, } \\
\text { Veratide-the anti-hypertensive brand in Germany from P\&G. }\end{array}$ \\
\hline Strides Arcolab Ltd. & 23 & 9 & $\begin{array}{l}\text { Brazil, Mexico, Italy, } \\
\text { Venezuela, Italy, } \\
\text { Australia, Norway, } \\
\text { Poland }\end{array}$ & $\begin{array}{l}\text { Strategic stake or acquisition of } 26 \text { percent in Brazil-based } \\
\text { Cellofarm Ltda, } 51 \text { percent in Brazil-based Infabra Industria } \\
\text { Farmaceutica Brasileria Ltda, } 52 \text { percent in Mexico_based Solara } \\
\text { S.A. De C.V., Italy-based Beltapharm S.p.A., Venezuela-based } \\
\text { Biopharma, Italy-based Diaspa SpA, drug houses of Australia } \\
\text { (Asia) Private Ltd., Norway-based Farma Plus, Poland-based sterile } \\
\text { manufacturing facility. }\end{array}$ \\
\hline $\begin{array}{l}\text { Glenmark } \\
\text { Pharmaceuticals Ltd. }\end{array}$ & 11 & 8 & $\begin{array}{l}\text { South Africa, Brazil, } \\
\text { Czech Republic, USA, } \\
\text { Argentina, Ireland, } \\
\text { Canada }\end{array}$ & $\begin{array}{l}\text { Strategic stake or acquisition of South Africa-based Bouwer } \\
\text { Bartlett Pty Ltd., Brand Uno-Ciclo from Brazil-based Instituto } \\
\text { Biochimico Indústria Farmacêutica Ltd., Brazil-based Laboratorios } \\
\text { Klinger Do Bras, Czech Republic-based Medicamenta, USA_based } \\
\text { Napo Pharmaceuticals Inc., Argentina-based Servycal SA, two } \\
\text { FDA approved products from Ireland-based Clonmel Healthcare } \\
\text { Ltd., two New biological Entities (NBE) from Canada-based } \\
\text { Chromos Molecular Systems Inc. }\end{array}$ \\
\hline $\begin{array}{l}\text { Sun Pharmaceutical } \\
\text { Industries Ltd. }\end{array}$ & 482 & 6 & USA, Hungary, Israel & $\begin{array}{l}\text { Strategic stake or acquisition of US-based Able Laboratories, } \\
\text { Israel-based Taro Pharmaceutical Industries Ltd., ICN CO Hungary } \\
\text { Ltd., three brands from US-based Women's First Healthcare, } \\
\text { Valeant Pharmaceuticals International's manufacturing facility } \\
\text { (Ohio). }\end{array}$ \\
\hline Aurobindo Pharma Ltd. & 23 & 5 & China, Italy, UK, USA & $\begin{array}{l}\text { Strategic stake or acquisition of China-based Shanxi Tongling } \\
\text { Pharmaceuticals and Shanghai Wide Tex Chemical Co Ltd., } \\
\text { intellectual property and marketing authorisations in Italy from } \\
\text { generic drug maker TAD, UK-based Milpharm Ltd., an USFDA } \\
\text { compliant cGMP manufacturing facility in US. }\end{array}$ \\
\hline $\begin{array}{l}\text { Dr Reddy's Laboratories } \\
\text { Ltd. }\end{array}$ & 683.8 & 5 & $\begin{array}{l}\text { Germany, UK, Spain, } \\
\text { Mexico, USA }\end{array}$ & $\begin{array}{l}\text { Strategic stake or acquisition of Germany-based Betapharm } \\
\text { Arzneimittel GmbH, UK-based BMS Laboratories and its } \\
\text { subsidiary Meridian Health Care, Spain-based Litaphar SA, Roche's } \\
\text { Active Pharmaceutical Ingredients (API) business in Mexico, US- }\end{array}$ \\
\hline
\end{tabular}




\begin{tabular}{|c|c|c|c|c|}
\hline & & & & based Trigenesis Therapeutics Inc. \\
\hline Jubilant Organosys Ltd. & 192 & 5 & USA, Belgium & $\begin{array}{l}\text { Strategic stake or acquisition of US-based Hollister-Stier } \\
\text { Laboratories, Belgium-based Pharmaceutical Services Incorporated } \\
\text { NV and PSI Supply NV, US-based Target Research Associates Inc, } \\
\text { US-based Trinity Laboratories Inc \& its wholly owned subsidiary } \\
\text { Trigen Laboratories Inc, a US generics company. }\end{array}$ \\
\hline $\begin{array}{l}\text { Nicholas Piramal India } \\
\text { Ltd. }\end{array}$ & 31 & 4 & UK, USA & $\begin{array}{l}\text { Strategic stake or acquisition of UK-based Avecia Pharmaceuticals, } \\
\text { Dobutrex brand rights from US-based Eli Lily \& Company in India, } \\
\text { global inhalation anaesthetics (IA) business of UK-based Rhodia } \\
\text { Organique Fine Ltd., Pfizer's drug making facility at Morpeth in } \\
\text { UK. }\end{array}$ \\
\hline Wockhardt Ltd. & 218.3 & 4 & $\begin{array}{l}\text { UK, Germany, USA, } \\
\text { Ireland }\end{array}$ & $\begin{array}{l}\text { Strategic stake or acquisition of UK-based CP Pharmaceuticals, } \\
\text { Germany-based Esparma Gmbh, US-based Morton Grove } \\
\text { Pharmaceuticals, Ireland-based Pinewood Laboratories. }\end{array}$ \\
\hline Cadila Healthcare Ltd & 35 & 3 & France, Japan, Brazil & $\begin{array}{l}\text { Strategic stake or acquisition of Alpharma SAS France, Japan- } \\
\text { based Nippon Universal Pharmaceuticals Ltd., Brazil-based } \\
\text { Quimica e Farmaceutica Nikkho do Brasil Ltda. }\end{array}$ \\
\hline $\begin{array}{l}\text { Dishman } \\
\text { Pharmaceuticals \& } \\
\text { Chemicals Ltd. }\end{array}$ & 80.8 & 3 & Switzerland, UK & $\begin{array}{l}\text { Strategic stake or acquisition of Switzerland-based Carbogen } \\
\text { AMC1S AG, Switzerland-based I03S of Bern, UK-based } \\
\text { Synprotec. }\end{array}$ \\
\hline Matrix Laboratories Ltd. & 263 & 3 & $\begin{array}{c}\text { Belgium, Switzerland, } \\
\text { China }\end{array}$ & $\begin{array}{l}\text { Strategic stake or acquisition of Belgium-based Docpharma, } \\
\text { Switzerland-based Explora Laboratories SA, China-based MCHEM } \\
\text { Pharma Group. }\end{array}$ \\
\hline Natco Pharma Ltd. & & 3 & USA & $\begin{array}{l}\text { Strategic stake or acquisition of assets of US-based Newark Drugs, } \\
\text { US-based NICK's drug store, US-based SaveMart Pharmacy. }\end{array}$ \\
\hline
\end{tabular}


In continuation of its acquisition strategy, Ranbaxy Laboratories entered into an agreement to buy France-based RPG (Aventis) SA along with its fully owned subsidiary, OPIH SARL, in December 2003 ${ }^{7}$. With this acquisition Ranbaxy Laboratories became the fifth largest generic player in France and got access to strong brand equity of the acquired unit and its strong product portfolio covering 52 molecules $^{8}$. To further strengthen its product portfolio, Ranbaxy Laboratories acquired a generic product portfolio consisting of 18 products belonging to the Spanish pharmaceutical company Efarmes SA in June 2005. Ranbaxy Laboratories' Regional Director for Europe, CIS \& Africa, Mr. Peter Burema described the significance of this acquisition as follows:

\begin{abstract}
"The acquisition fortifies our presence in Spain while augmenting our existing product portfolio. With this strategic development, we will be able to provide a wide range of quality generics to meet the growing needs of patients in this part of the world ${ }^{9}$."
\end{abstract}

The year 2006 has been a watershed year for acquisition strategy of Ranbaxy Laboratories with as many as five overseas acquisitions. In March 2006, Ranbaxy Laboratories acquired Allen generic business from GlaxoSmithKline in Italy and one generic company each in Romania and Belgium. The product portfolio acquisition is a route to fast track growth in Italy with Ranbaxy Laboratories deriving strong advantages from product complementarities in the short term and catering to the business opportunities that will be thrown open by future patent expiries $^{10}$. The acquisition of Terapia is an important strategy for acquiring new knowledge and strong market presence in Europe. The acquired unit had strong distribution and marketing network in the Romanian pharmaceutical market with a wide range of portfolio and new product pipeline, excellent R\&D capabilities, world class in-house bioequivalence facilities and low cost manufacturing facilities. According to Mr. Malvinder Mohan Singh, CEO \& Managing Director, Ranbaxy Laboratories:

\begin{abstract}
"Terapia represents exceptional value for our stakeholders. Within the Ranbaxy fold, it unleashes multiple synergies of product development, product flow, low cost manufacturing, proximity and access to high growth markets, in country presence and sound fundamentals while being EPS accretive to the group immediately. The transaction is compelling and furthers us on our path to becoming a top five global generic company ${ }^{11}$."
\end{abstract}

Ethimed NV-the acquired company is $10^{\text {th }}$ largest generic company in Belgium with over 20 product registrations and a significant customer network ${ }^{12}$. Clearly, this acquisition has been to further strengthen the global position of Ranbaxy in generic space. In July 2006,

\footnotetext{
${ }^{7}$ Ranbaxy Press Release (2003), Ranbaxy to acquire RPG (Aventis) in France to propel European expansion, December 13.

${ }^{8}$ Ranbaxy Press Release (2004), 'Ranbaxy now fifth largest generic supplier in France', January 05.

${ }^{9}$ Ranbaxy Press Release (2005), 'Ranbaxy acquires generic product portfolio from Efarmes of Spain', June 09.

${ }^{10}$ Ranbaxy Press Release (2006) 'Ranbaxy to acquire the unbranded generic business of Glaxosmithkline in Italy', March 27.

${ }^{11}$ Ranbaxy Press Release (2006), 'Ranbaxy acquires leading Romanian pharma company Terapia for US \$324M', March 29.

${ }^{12}$ Ranbaxy Press Release (2006), 'Ranbaxy acquires Ethimed in Belgium', December 30.
} 
Ranbaxy Laboratories has acquired the Mundogen generic business of GlaxoSmithKline (GSK) in Spain. Apart from consolidating Ranbaxy's presence in the rapidly growing Spanish generic market, this acquisition intends to strengthen its product portfolio ${ }^{13}$.

With a move to expand its South African presence, Ranbaxy Laboratories acquired BeTabs Pharmaceuticals (Pty) Limited in December 2006. The acquired entity ranked fifth in the South African generic market and is the largest manufacturer of Penicillin formulations with ownership of a portfolio of ethical and over-the-counter (OTC) solid-oral and liquid formulations. The strategic motivation behind this acquisition has been summed up by $\mathrm{Mr}$. Malvinder Mohan Singh as follows:

“The acquisition of Be-Tabs' results in considerable synergies and further strengthens Ranbaxy's foothold in South Africa. It reinforces our position by expanding our portfolio in a key market that is exhibiting strong growth potential. The move will help us to provide effective disease management solutions in support of the government's objective to make healthcare affordable to a wider cross-section of the population ${ }^{14}$."

\title{
3.2.2. Strides Arcolab Ltd.
}

With 9 overseas acquisition deals, Stride Arcolab is the second most aggressive acquirer from Indian pharmaceutical industry. By the late 1990s, Stride Arcolab has realized the inadequacy of its own process innovation strategy to meet new challenges of TRIPS-based technological regime and started putting substantial focus on product development paradigm. The CEO and Managing Director of the company, Mr. Arun Kumar, stated this changing technological strategy of the company in following manner:

\begin{abstract}
"In preparation for the future, we have embarked on an aggressive product development strategy. Our newly created state-of-the-art product development centre in Bangalore will enable us to launch newer products at shorter intervals enabling a large portfolio of products both in nutraceuticals and generics. Our process development centre in Mangalore will enable the speciality chemicals division in its cost-cutting endeavors and will provide cutting edge manufacturing and process technologies”. Stride Arcolab Annual Report, 1999, pp. 13.
\end{abstract}

The underlying desire of the company to broaden its geographical operation and global manufacturing scale led it to consistently pursue the route of overseas acquisition. In October 1999, the company acquired a soft gelatin capsule manufacturing plant in New Jersey, USA. This acquisition has added substantial manufacturing capabilities to allow Stride Arcolab to be a major player in the international soft gelatin market. In 2001-02, the company undertook a total of three foreign acquisitions targeted at Brazil and Mexico. It has acquired 52 per cent stake in Solara Farmaceutica to enter into the fast growing Mexican market. This acquisition provided access to a state-of-the-art commissioned manufacturing facility by Solara for tablet and capsules. The acquisition of 52 per cent strategic stake in Infabra Industria Farmaceutica, Brazil enables Stride Arcolab to get access to 48 product registrations belonging to Infabra. This

\footnotetext{
${ }^{13}$ Ranbaxy Press Release (2006), 'Ranbaxy to acquire the Mundogen generic business of Glaxosmithkline in Spain', July 18.

${ }^{14}$ Ranbaxy Press Release (2006), 'Ranbaxy Acquires Be-Tabs Pharmaceuticals, the 5th largest generics company in South Africa for USD 70 MN', December 01.
} 
acquisition along with the acquisition of 26 per cent in Cellofarm Ltda greatly expanded Stride Arcolab's presence in the Brazilian pharmaceutical markets.

After consolidating acquired overseas entities and integrating them with the company during 2003-2004, Stride Arcolab went for second round of M\&A with acquiring three entities in 2005. Besides acquiring sterile manufacturing facility in Poland, it acquired Beltapharm in Italy and Biopharma in Venezuela. Mr. Arun Kumar expressed the importance of polish acquisition as follows:

"The facility at Poland represents a unique opportunity for the company to establish a manufacturing presence in Central Europe as well as expand its portfolio and business of finished forms. The Polish facility will give easier access to Europe at a low operating cost. The site has an excellent team and adequate space to take up expansions at a very low incremental cost ${ }^{15}$."

In addition to acquiring Drug Houses of Australia (Asia) Private Limited (DHA) in 2006, Strides Arcolab acquired Diaspa's USFDA approved Italian fermentation facility and Norwaybased Farma Plus in 2007. Singapore-based DHA is a very old generics company with GMP certified manufacturing facility. Besides being one of the leading branded generics player in Singapore, the acquired entity has important presence in Malaysia and Hong Kong. This acquisition is a key strategy of Strides Arcolab to grow in these regional markets and to create a strong regional brand image ${ }^{16}$. The acquisition of Farma Plus-an emerging player of hospital products in the Scandinavian market-is more of a market entry strategy. However, the acquisition of Milan fermentation assets of Disapa is clearly a strategic move by the company, which Mr. Arun Kumar summed up as follows:

"The acquisition will give us immediate access to a USFDA and EU approved facility with strong history of technology and fermentation skills. A significant part of Strides dosage form businesses are based on fermentation active pharmaceutical ingredients (APIs). Diaspa delivers the integration needs for us in this crucial space. We further intend to harness the existing customer base and product capabilities of Diaspa and aim to become a leading player in the fermentation space. We are also delighted with the strong technology and management bandwidth Diaspa brings along with this acquisition ${ }^{17 "}$.

\subsubsection{Glenmark Pharmaceuticals Ltd.}

The third largest overseas acquirer from Indian pharmaceutical sector is Glenmark Pharmaceuticals with a total of 8 acquisition deals. The company was very early to appreciate the role of acquisition in creating essential capabilities for the challenges thrown up by product patent regime and global competition. The 1999-2000 Annual Report of the company explicitly mentioned acquisition as a potential growth strategy: "In its onward growth, Glenmark will continue to consider appropriate company and brand acquisition opportunities to enhance its portfolio" (pp. 8).

Its first overseas acquisition was the Brazil-based Laboratorios Klinger in April 2004.

\footnotetext{
${ }^{15}$ Hindu Business Line (2005), 'Strides Arcolab to buy Polish co, take 70 pc stake in Italian venture', August 02.

${ }^{16} \mathrm{http}: / / w w w . d o m a i n-b . c o m(2006)$, 'Strides Arcolab to acquire drug unit in Singapore', September 01.

${ }^{17}$ Business Standard (2007), 'Strides Arcolab to acquire Diaspa's Milan unit', May 29.
} 
The acquired entity had 21 approved product registrations in Brazil covering braded generics and OTC products. This acquisition was overwhelmingly a market entry strategy into the largest pharmaceutical market in South America and to quickly enhance market presence. In August 2004, Glenmark acquired two FDA approved products from Clonmel Healthcare Ltd. As per Jeffrey Weiss, CEO, Glenmark Pharmaceutical Inc, this acquisition will accelerate Glenmark's product growth plan in the US ${ }^{18}$. In March 2005, it acquired the exclusive manufacturing and marketing global rights of a leading hormonal brand, Uno-Ciclo from Instituto Biochimico Indústria Farmacêutica Ltda. Mr. Glenn Saldanha, Managing Director and CEO of Glenmark Pharmaceutical further emphasized this product acquisition strategy as:

\section{"The purchase of Uno-Ciclo is another step towards enhancing our product basket and extending our reach in Brazil and the Latin American region”.}

The acquisition of Servycal SA - an Argentine marketing company with a basket of 17 approved product registrations and additional three products pending registration-in October 2006 represent Glenmark's direct entry strategy into Argentina. Apart from accessing Servycal's strong retail and hospital presence in Argentina, this acquisition enhances Glenmark's geographical presence in 12 other South American country markets where Servycal's products are registered $^{19}$. To further expand its geographical spread and width of product offerings, it has acquired Bouwer Bartlett Pty - a South African sales and marketing company in December 2005. Mr. Glenn Saldanha offered following comment on this acquisition ${ }^{20}$ :

\footnotetext{
"The purchase of Bouwer Bartlett is part of our long-term strategy to emerge as a speciality/brand company marketing novel drugs, by acquiring front-ends in key markets outside the USA, the EU and Japan."
}

The year 2006 saw Glenmark acquiring new product than acquisition of companies or manufacturing assets. To accelerate its product-focused generics presence in the US market, Glenmark acquired manufacturing and marketing rights of 2 liquid generic pharmaceutical products from Lehigh Valley Technologies Inc. and another 3 generic controlled-substance pharmaceutical products from Aspen USA Inc. in May 2006. Another 7 products of Lehigh Valley Technologies targeted at the US market were acquired by the company in December 2006. In June 2006, it has acquired global intellectual property rights of 7 products and 11 presentations from P D Pharmaceuticals (Pty), South Africa.

In March 2007, Glenmark acquired the company Medicamenta to get its first commercial foothold into the strategically important market of Europe. The acquitted entity with its basket of 29 products has significant branded presence and strong sales and marketing operations in both Czech Republic and Slovakia. The President of Glenmark Europe, Guy Clark, while describing

\footnotetext{
${ }^{18}$ Gleenmark Press Release (2004), 'Glenmark Pharmaceuticals Inc., USA, acquires ANDAs from Clonmel Inc. and files its first complete Para 3 ANDA in the US', August 30.

${ }^{19}$ Gleenmark Press Release (2005), 'Glenmark acquires Servycal S. A., a marketing company in Argentina' October 26.

${ }^{20}$ Gleenmark Press Release (2005), 'Glenmark acquires Bouwer Bartlett Pty. Ltd., a sales and marketing company in South Africa, December 26.
} 
this acquisition has stated:

"This is the first of many steps that Glenmark will take on its journey to build a significant
branded presence in the important market of Europe, and Medicamenta will also provide a
geographically central base to support Glenmark's other European distribution activities."

In July 2007, Glenmark acquired two new biological entities (NBE) from Canada-based Chromos Molecular Systems Inc to expand and diversify its product portfolio.

\subsubsection{Sun Pharmaceutical Industries Ltd.}

By 1990s, Sun Pharmaceutical with its strategy of serving niche high-margin market segments such as psychiatry and central nervous system drugs gained a good presence in the domestic market. The second half of 1990s witnessed Sun Pharmaceutical adopting a series of domestic acquisition to enlarge its product range and manufacturing capacity to emerge as a national player. After achieving rapid expansion in national market, Sun Pharmaceutical saw the emerging generics opportunities in the US and decided to extend its acquisition strategy to cover this overseas market.

Caraco Pharmaceutical Laboratories-a Detroit based manufacturer of generic pharmaceuticals is the first overseas acquisition made by Sun Pharmaceutical. This acquisition was an entry strategy into the lucrative US generics market and was completed in successive equity stake enhancement in 1997, 2002, 2003 and 2004. Sun Pharmaceutical viewed Caraco as a vehicle to get USFDA approval for its own generic products in the US and market introduction. The acquisition of three niche brands from the US-based Women's First Healthcare in September 2004, marked Sun Pharmaceutical's initial attempt in the US branded generic space. In 2005, it has acquired Valeant Pharmaceuticals' Ohio manufacturing facility and US-based Able Laboratories. The Ohio manufacturing facility is expected to help Sun Pharmaceutical in reaping emerging opportunities in liquids and semi-solids like creams and ointments and in speeding up filings for the US generic market. By acquiring the rights to entire product line that were being marketed by Able Laboratories and its dosage-form manufacturing facilities, Sun Pharmaceutical has significantly expanded its US operation.

Sun Pharmaceutical expanded its global manufacturing base by acquiring Hungary-based Valeant's raw materials and dosage-form manufacturing operations in August 2005. This became Sun Pharmaceutical's first European manufacturing base. In May 2007, it entered into definitive agreements to acquire Israel-based Taro Pharmaceutical Industries with established subsidiaries, manufacturing facilities and products across the US, Canada, Israel and Ireland. The acquired entity has strong product baskets in dermatology, cardiovascular, neuropsychiatric and anti-inflammatory therapeutic categories and possesses world-class manufacturing facilities with necessary regulatory approvals in operating markets. In the US market it has more than 100 ANDA (Abbreviated New Drug Application) approvals from USFDA with additional 26 ANDAs awaiting approval. By July 2008, Sun pharmaceutical has already acquired 36 per cent stake in Taro and has initiated a hostile bid to acquire additional 12 per cent stake from 
controlling shareholders in July 2008.

\title{
3.2.5. Dr. Reddy's Laboratories Ltd.
}

For Dr. Reddy's Laboratories, acquisition and consolidation is a means of improving R\&D performance and enlarging the scale required to meet emerging hyper competitive market environment. The 1999-2000 Annual Report of Dr. Reddy's Laboratories make this point very clear:

\begin{abstract}
"Worldwide, pharmaceutical companies are under pressure to consolidate-largely driven by the need to fund innovative $R \& D$ while gaining critical mass. The consolidation activity at $D r$. Reddy's Laboratories in 1999-2000 echoes this global trend. The merger of group company, Cheminor Drugs with the flagship and the acquisition of American Remedies were moves in this direction. The unified company has emerged as India's third largest pharmaceutical player with revenues expected to reach Rs. 1000 crores in the financial year 2000-01.
\end{abstract}

The competencies of Dr. Reddy's Laboratories now cover the entire pharmaceutical value chain from basic research to bulk actives to branded formulations and generics, and on to emerging areas such as custom chemical synthesis, diagnostics and biotechnology. Further it has helped the company acquire a global reach, with presence in all major world markets and form an extensive product portfolio." (pp. 9).

Having experimented with acquisitions within the national boundary, Dr. Reddy's Laboratories begin to explore the advantages of acquisition strategy in overseas markets. In April 2002, Dr. Reddy's Laboratories went for its first overseas acquisition and acquired BMS Laboratories and its subsidiary, Meridian Healthcare UK Limited. The acquired group had two fully-integrated manufacturing facilities and is currently marketing more than 30 generic products and possessing another 70 product licenses. Mr. GV Prasad, CEO, Dr Reddy's Laboratories, put below his vision behind this acquisition:

"This acquisition is a key step in our efforts to globalise our business. It gives us entry into the UK generics market through the BMS Group's established product basket and strong marketing network. We expect it to jumpstart our generics business in $U K^{21}$."

In May 2004, Dr. Reddy's Laboratories acquired US-based Trigenesis Therapeutics, Inc mainly to access latter's proprietary drug delivery technology platforms in the dermatology segment. According to Mr. GV Prasad, this acquisition is an important element of the overall corporate strategy being followed by Dr. Reddy's Laboratories to emerge as a specialty pharmaceutical company focused on the US market. While commenting on this acquisition, he said:

"This deal provides us an exciting opportunity to apply various proprietary drug delivery technologies in creating a pipeline of differentiated drugs that will broaden the range of

\footnotetext{
${ }^{21}$ Dr Reddy Press Release (2004), 'Dr Reddy's signs definitive agreement to acquire BMS Laboratories and Meridian Healthcare UK', March 12.
} 
available treatment options and establish Dr. Reddy's in the prescription dermatology segment ${ }^{22}$."

The upgradation of global scale, geographical spread and product diversification through acquisition by Dr. Reddy's Laboratories continued even more strategically. The acquisition of Roche's API business in November 2005 marked Dr. Reddy's Laboratories' inclination to acquire new innovative capabilities in the API (Active Pharmaceutical Ingredient) space and custom pharmaceutical services. Mr. GV Prasad provided the following rationale for this acquisition:

\begin{abstract}
"With the acquisition of Roche's API business at the Mexico site, Dr. Reddy's will emerge as a leading player in Custom Pharmaceutical Services (CPS) business and position itself as a partner of choice for Innovator Companies across the globe with service offerings spanning the entire value chain of pharmaceutical services. This strategic acquisition provides an opportunity for our CPS business to grow from the current base of USD10 million to USD100 million over the next 18 months. The integration of these businesses - people and technology; the expertise of the management team and distinctive manufacturing capability at the Mexico site, with that of Dr. Reddy's strengths in process chemistry and world class research capabilities will provide a strong foundation to drive the next wave of growth in our CPS business ${ }^{23}$."
\end{abstract}

In 2006, Dr Reddy's Laboratories acquired Betapharm Arzneimittel GmbH in Germany and Litaphar S.A in Spain. The acquisition of Betapharm-the fourth-largest generics company in Germany-provides ample evidence to the fact that Dr Reddy's Laboratories' overseas acquisition strategy has matured considerably. The acquisition of Betapharm, which operates on high-quality generic drugs with high prescription rates and a strong track record of successful product launches, is a logical strategy for Dr Reddy's Laboratories to consolidate its global size and fostering technological developments. This acquisition immediately provided Dr Reddy's Laboratories a critical size in Europe, a leading market position and a portfolio covering 145 marketed products. The strategic benefits that have driven this acquisition can be seen from what Mr. GV Prasad had said:

\begin{abstract}
"We are very excited with our strategic investment in betapharm. betapharm with its differentiated business model has all the key elements for achieving success in the fast growing generics market in Germany. We strongly believe that this strategic investment will generate substantial opportunities for long-term value creation for both the companies. The combination of these two companies will enable betapharm to continue to expand its growth trajectory and at the same time provide a strong foundation to leverage Dr. Reddy's global product development and marketing infrastructure to build a significant generics business in Europe in the long-term. We are excited to partner with the highly dedicated and motivated team at betapharm to build a future of growth and leadership for Dr. Reddy's as well as betapharm ${ }^{24} . "$
\end{abstract}

\footnotetext{
${ }^{22}$ Dr Reddy Press Release (2002), 'Dr. Reddy's acquires access to Drug Delivery Technology Platforms in the Dermatology Segment: Marks Company's foray into the \$6 billion niche dermatology segment in the US' May 06.

${ }^{23}$ Dr Reddy Press Release (2005), 'Dr. Reddy's signs definitive agreement to acquire Roche's API business at its Mexico facility', November 08 .
} 
In May 2006, Dr Reddy's Laboratories acquired marketing authorizations and marketing authorization applications for certain specialty pharmaceutical products, along with the related trademark rights and physical inventories from Laboratorios Litaphar in Spain. Very recently, it has engaged in three overseas acquisition deals-Dowpharma Small Molecules business associated with Dow's Mirfield and Cambridge in UK, BASF's pharmaceutical contract manufacturing business and related facility in Shreveport, Louisiana, USA and an Italian company, Jet Generici Srl-all in April 2008. The Italian acquisition provided Dr Reddy's Laboratories' access to an essential product portfolio, a pipeline of registration applications, and a sales and marketing organization ${ }^{25}$. Following rationales were offered by the company managers behind the UK and US acquisition:

\begin{abstract}
"The proprietary chiral and biocatalysis technology at the Cambridge site and the scale up capability in the Mirfield site will add significant value to the company. This acquisition will also bring strengths in industrial synthesis of complex prostaglandins and carbohydrate chemistry. These newer capabilities will add to our existing $R \& D$ and commercial infrastructure to position Dr. Reddy's as a leading provider of Custom Pharmaceutical Services globally ${ }^{26}$." Satish Reddy, Managing Director \& Chief Operating Officer, Dr. Reddy's Laboratories
\end{abstract}

\begin{abstract}
"We are excited about this acquisition as this facility provides us with a profitable revenue base built on strong customer relationships with branded and generic companies. It also provides us with an additional platform to further expand our portfolio of prescription generics, OTC capabilities and product portfolio and the ability to supply generic products to US government agencies ${ }^{27}$." Mark Hartman, President, North America Generics, Dr. Reddy's Laboratories.
\end{abstract}

Clearly, the foregoing brief reviews on the experience of selected Indian pharmaceutical companies do indicate that they are using overseas acquisitions to expand their global market presence in addition to getting access to new products, marketing and managerial skills, and quality standards. With this newly gained knowledge they are expected to overcome their existing innovation barrier such as small size of their product portfolio primarily nurtured through process technological activities in the home country. In case these Indian pharmaceutical firms are able to integrate acquired new knowledge and efficiently absorb them for further knowledge developments, this overseas acquisition wave from India will have profound effects on both home and host countries. India will witness the emergence of truly global Indian firms based on advance knowledge and host countries are likely to benefit from supply of costeffective life-saving drugs and generics by Indian companies.

\footnotetext{
${ }^{24}$ Dr Reddy Press Release (2006), 'Dr. Reddy's signs definitive agreement with $3 i$ for the strategic acquisition of Betapharm', February 16.

${ }^{25}$ Dr Reddy Press Release (2008), 'Dr. Reddy’s acquires Jet Generici Srl. Acquisition to establish Generics business in Italy', April 03.

${ }^{26}$ Dr Reddy Press Release (2008), 'Dr. Reddy's signs definitive agreement to acquire Dowpharma Small Molecules business associated with Dow's Mirfield and Cambridge, UK Sites', April 01.

${ }^{27}$ Dr Reddy Press Release (2008), 'Dr. Reddy's Acquires BASF's Pharmaceutical Contract Manufacturing Business and related facility at Shreveport in the US', April 30.
} 


\section{Concluding Remarks}

Initial constraints of being a developing country and non-existent productive base in modern pharmaceutical sector notwithstanding, India could build a very competitive pharmaceutical industry. The strategic government policies including public sector drug production, adoption of short duration process patent regime and strong monitoring of activities of foreign companies, resulted in significant growth of domestic investment in the pharmaceutical sector and increased local technological activities mainly in the form of costeffective process development. This led to rising domestic productive capacity to satisfy growing demand for drugs and prompted a consistent export surge to overseas markets.

It is since 1990s the issue of a broad-based innovation strategy for long run growth of Indian pharmaceutical firms started attracting corporate and expert attention. The liberalization measures and a product patent regime made it imperative that Indian pharmaceutical firms must enlarge their innovation strategy towards product oriented R\&D. Indian pharmaceutical firms without enhancing in-house capabilities to enlarge product portfolio are going to face more survival challenges in coming years. Many capable Indian pharmaceutical companies are early to realize these challenges and have gone for suitable measures like putting more resources for product and process development. In addition, they have also opted for overseas acquisition as a favourite strategy to overcome their inadequate product development and other intangible capabilities. Thus, the recent boom in overseas acquisitions by Indian pharmaceutical firms represents the strategic motivation of acquiring new products, new markets, skills and technologies. Brief case studies of five acquirers from Indian pharmaceutical sector further testify the desire of Indian companies to improve their competitive advantages by accessing new technologies and products. In this sense overseas acquisition can be seen as a means of overcoming limited product development capabilities that characterizes majority of Indian pharmaceutical companies.

Although overseas acquisition can be important for enhancing firm-specific technological capabilities and for entering into new markets, they are also challenging for acquiring Indian pharmaceutical firms in a number of ways. Investment requirements in acquisition are quite substantial and not all Indian pharmaceutical firms have access to such resources. Especially, small- and medium-sized pharmaceutical units that dominate the Indian pharmaceutical industry shall not be able to benefit from the acquisition strategy. They don't have financial, technological and skill resources to undertake overseas acquisition to improve their product portfolio. Therefore, the scope and opportunities that are associated with acquisition strategy are limited to relatively large Indian pharmaceutical companies.

Since Indian pharmaceutical companies are new to global production, overseas acquisition involves significant market and operational risks. In the preparatory stage, the challenge is to decide on target markets and to identify target companies that can fit well into the requirements of Indian acquiring companies. In addition, Indian firms are required to determine the transaction value, negotiate with potential target companies and obtain information related to host country legal and environment clearances. Although financial accounting and consultancy firms help in these efforts, Indian firms should have adequate in-house skills to manage these issues more realistically. Insufficient knowledge of host country laws, regulatory delays, strong legal monitoring in host developed countries related to manufacturing process and quality of drugs and unexpected changes therein, rapid changes in demand and prices, growing 
competition, etc., represents high risk entail in overseas acquisition.

After acquisition, an Indian firm faces operational challenge to carry forward acquired production activities in foreign countries. The immediate issue is the post-acquisition integration that addresses the theme of harmonizing different work cultures, managerial practices, employment policies, etc., to successfully integrate the acquired overseas units and put it to efficient production. The scope for absorbing newly acquired foreign knowledge and benefiting from scale expansion clearly depends on the technological capabilities of acquirers themselves.

It is clear that without a well designed acquisition strategy, acquiring Indian pharmaceutical companies may not realize intended benefits from such activities. As long as Indian acquiring firms are aware of the potential risks involved in acquisition and well prepared to face such eventualities, overseas acquisitions can contribute to their greater geographical and economic diversification and upgrading of their technological capabilities significantly. 


\section{References}

Aggarwal, A (2007) 'Pharmaceutical Industry' in N. Kumar and KJ Joseph (eds.) International Competitiveness and Knowledge-based Industries in India, Oxford University Press: New Delhi, pp. 143-184,.

Joseph, N.I. (1979), 'Multinationals in the Indian Drug Industry', Social Scientist, Vol. 7, No. 8/9, Multinationals and Underdevelopment, pp. 78-89.

Lanjouw J.O. (1998), 'The Introduction of pharmaceutical Product Patents in India: Heartless Exploitation of the Poor and Suffering?' NBER working paper 6366.

Pradhan, J.P. (2007), 'Strengthening Intellectual Property Rights Globally: Impact on India's Pharmaceutical Exports', Singapore Economic Review, 52, pp. 233-250.

Pradhan, J.P. (2008), 'Indian Direct Investment in Developing Countries: Emerging Trends and Development Impacts', ISID Working Paper No. 2008/08, Institute for Studies in Industrial Development, New Delhi.

Pradhan, J.P. and A. Alakshendra (2006), 'Overseas Acquisition versus Greenfield Foreign Investment: Which Internationalization Strategy is better for Indian Pharmaceutical Enterprises?', ISID Working Paper, No. WP2006/07, Institute for Studies in Industrial Development, New Delhi.

Pradhan, J.P. and PP Sahu (2008), Transnationalization of Indian Pharmaceutical SMEs, Bookwell Publisher, New Delhi. 